P I C T U R I N G R U S S A 
This page intentionally left blank 


\section{Picturing Russia}

\section{Explorations in Visual Culture}

Edited by

Valerie A. Kivelson and Joan Neuberger 
Published with assistance from the Mary Cady Tew Memorial Fund.

Copyright $\odot 2008$ by Yale University.

All rights reserved. This book may not be reproduced, in whole or in part, including illustrations, in any form (beyond that copying permitted by Sections 107 and 108 of the U.S. Copyright Law and except by reviewers for the public press), without written permission from the publishers.

Designed by Mary Valencia

Set in Minion by Tseng Information Systems, Inc.

Printed in the United States of America by Sheridan Books, Ann Arbor, Michigan.

Library of Congress Cataloging-in-Publication Data

Picturing Russia : explorations in visual culture / edited by Valerie A. Kivelson and Joan Neuberger.

p. $\mathrm{cm}$.

Includes bibliographical references and index.

ISBN 978-0-300-11961-9 (alk. paper)

1. Art, Russian. 2. Russia-In art. 3. Art and history. 4. Visual communication. I. Kivelson, Valerie A. (Valerie Ann) II. Neuberger, Joan, 1953-

N6981.P53 2008

709.4709

2007039315

A catalogue record for this book is available from the British Library.

The paper in this book meets the guidelines for permanence and durability of the Committee on Production Guidelines for Book Longevity of the Council on Library Resources.

$\begin{array}{llllllllll}10 & 9 & 8 & 7 & 6 & 5 & 4 & 3 & 2 & 1\end{array}$ 
We dedicate this joint project to our fathers:

Daniel Kivelson

July 11, 1929-January 23, 2003

Henry L. Neuberger

July 11, 1921-January 23, 2004 
This page intentionally left blank 